This work was supported in part by a grant from the U.S. National Institutes of Health. It was presented (in part) at the 78th Endocrine Society meeting, Chicago, June 1966.

Endocrine and Polypeptide Laboratories,

AbBa J. Kastin

Andrew V. Schat,Ly

Veterans Administration Hospital,

and

Department of Modicine,

Tulane University School of Medicine,

New Orleans, Louisiana.

' Etkin, W., Gen. Comp. Endocrinol. (suppl.), 1, 148 (1962).

Kastin, A. J., and Ross, G. 'T., Endocrinology, '77, 45 (1965).

"Kastin, A. J., and Schally, A. V., Gen. Comp. Endocrinol., 7, 452 (1966).

' Schally, A. V., and Kastin, A. J., Endocrinology, 79, 768 (1966).

Kastin, A. J., and Ross, G. T., Endocrinology, 75, 187 (1961).

Kastin, A. J., and Schally, A. V., Endocrinology, 79, 1018 (1966).

Scott, G. T., and Nading, L. K., Proc. Soc. Exp. Biol. and Med., 106, 88 (1961).

Case, J. D., and Wright, M. R., Fed. Proc., 19, 282 (1960).

Kastin, A. J., and Schally, A. V., Experientia, 22, 389 (1966).

${ }^{n}$ Baschieri, L., De Luca, F., Cramarossa, L., DeMartino, C., Oliverio, A,, and Negri, M., Experientia, 19, 15 (1963).

'Bowers, C. Y., Redding, T. W., and Schally, A. V., Endocrinology, 74, 559 (1964).

Kastin, A. J., and Ross, G. T., Experientia, 20, 461 (1964).

is Taleisnik, S., and Orias, R., Amer. J. Physiol.,208, 293 (1965).

" Kastin, A. J., Prog. Forty-seventh Endocrine Soc. Meeting, 198 (1965).

schally, A. V., Bowers, C. Y., and Locke, W., Amer. J. Med. Sci., 248, 113 (1964).

\section{Distribution of Cytochrome Oxidase, Monoamine Oxidase and Carbonic Anhydrase in the Carotid Body of the Rabbit}

Joels and Neil ${ }^{1}$ showed that a high concentration of carbon monoxide in the fluid perfusing the carotid body of a cat produced an increase in discharge rate in the carotid sinus nerve. Carbon monoxide forms an unstable complex with the iron atom in cytochrome oxidase and this is broken down by strong light; illumination of the carotid body perfused with a large concentration of carbon monoxide reduces the intensity of the discharge induced by carbon monoxide. This was interpreted by Joels and Neil ${ }^{1}$ to indicate the presence of cytochrome oxidase in the carotid body. Lee and Mattenheimer ${ }^{2}$, however, found only very low cytochrome oxidase activity in the carotid body glomus tissue of slaughterhouse-killed bullocks. The distribution of monoamine oxidase is of interest in connexion with the large concentration of a catecholamine, which appears to be dopamine, in the chemoreceptor or type I glomus cells ${ }^{3}$, and the possibility of a catecholamine acting as a transmitter in this tissue as suggested by Lever and Lewis ${ }^{4}$. Carbonic anhydrase activity was found to be high in the glomus tissue by Lee and Mattenheimer ${ }^{2}$, who used a histochemical method, but they did not examine its distribution within the glomus tissue. Black, McCloskey and Torrance ${ }^{5}$ showed that inhibiting carbonic anhydrase with sodium acetazolamide slowed the carbon dioxide response of the cat carotid body.

The distribution of cytochrome oxidase, monoamine oxidase and carbonic anhydrase has now been investigated in the course of other work on the rabbit's carotid body. The animals were killed by a blow on the head. The carotid bodies were removed immediately and frozen on to a microtome chuck with a carbon dioxide freezer. Sections $20 \mu$ thick were cut in a cryostat and floated on to the incubation media for the three enzymes. In addition, six carotid bodies were perfused through the carotid artery with 2.5 per cent glutaraldehyde in $0 \cdot 1$

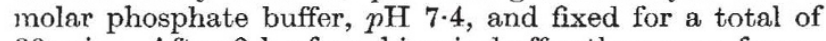
$30 \mathrm{~min}$. After $2 \mathrm{~h}$ of washing in buffer they were frozen on to a microtome chuck and cut in tho cryostat.

Cytochrome oxidase was demonstrated on sections of fresh tissue by the method of Burstone ${ }^{6}$ with $p$-aminodiphenylamine and 1-hydroxy-2-naphthoic acid or 8-amino1,2,3,4-tetrahydroquinolino as the coupling agent. The method of Glenner, Burtner and Brown ${ }^{7}$ was used to show monoamine oxidase in unfixed tissue sections and that of Morris and Swayne ${ }^{8}$ for carbonic anhydrase on sections of both fresh and fixed tissue.

Cytochrome oxidase, with 1-hydroxy-2-naphthoic acid as the coupling agent, gave a red-brown colour which faded within 1 month. Tho precipitate with 8-amino1,2,3,4-tetrahydroquinoline was dark blue and did not fade noticeably over 2 months. With both agents the colour was confined to the type I glomus cells. The precipitate was granular and the granules were of the same size as the mitochondria seen in electron micrographs of type I cells. It was absent from nerve fibres and connective tissue and only faint in the smooth muscle of blood vessels. The sustentacular or type II glomus cells could not be distinguished on the surface of the type I cells.

Monoamine oxidase activity is shown by a dark blue formazan precipitate in the method used. It was found in the cytoplasm of elongated or irregular cells surrounding the groups of type I cells in a single layer. These cells with nuclei much smaller than those of the type I cells are probably type II cells. Connective tissue did not stain, but some myelinated nerve fibres showed a granular deposit.

The final reaction product of the carbonic anhydrase method is black cobalt sulphide. The groups of glomus cells were strongly stained; in fresh tissue sections the precipitate was granular and largely confined to the cytoplasm of type I cells. In the fixed material the reaction was stronger but less well localized, although it was still heaviest in the type I cells. Any red cells present stained, and a few nerve bundles as well. Con. nective tissues did not stain. All staining was prevented by including 5 mmolar sodium acetazolamide in the incubation medium. The enzyme appears to be localized in type I cells though results obtained with the usual methods for this enzyme have been criticized by Pearse" and by Arvy ${ }^{10}$.

RODERICK I. WOODS*

University Laboratory of Physiology,

Oxford.

- Medical Research Council scholar.

${ }^{1}$ Joels, N., and Neil, E., Arch. Intern. Pharmacodyn., 139, 528 (1962).

${ }^{2}$ Lee, K. D., and Mattenheimer, H., Enzymol. Biol. Clin., 4, 199 (1964).

${ }^{3}$ Fillenz, M., and Woods, R. T., J. Physiol., 186, 39-40P (1966).

4 Lever, J. D., and Lewis, P. R., J. Physiol., 149, 26P (1959).

s Black, A. M. S., McCloskey, D. I., and Torrance, R. W., J. Physiol., 185 67-68P (1966).

"Burstone, M. S., Enzyme Histochemistry and its Applications in the Study of Neoplasms (Academic Press Inc., London, 1962).

${ }^{7}$ Glenner, G. G., Burtner, H. J., and Brown, G. W., J. Histochem. Cytochem. 5,591 (1957).

'Morris, G. C. R., and Swayne, G. W., J. Physiol.,171, 5 (1964).

' Pearse, A. G. E., Histochemistry-Theoretical and Applied, 597 (J. and A. Churchill, London, 1960).

${ }^{10}$ Arvy, L., Ann. Histochim., 8, 373 (1963).

\section{Nature of the Variation in Flower Colour in Vicia}

From earlier work it was concluded that the principal factor concerned in promoting blueness in anthocyaninpigmented flowers of Lathyrus species was the presence of flavonol co-pigments ${ }^{1,2}$. It was of interest to extend the observations into the related genus Vicia to determine whether a similar conclusion might be reached. In the latter gonus the range of flower colour is similar to that found in Lathyrus. Species were selected for investigation which gave some representation of the colour range. Hydrolysed extracts of standard and wing petals were prepared and then examined by filter paper chromatography as described earlier ${ }^{1}$.

As in wild material of Lathyrus, the anthocyanins are glycosides of delphinidin and its related methylated derivatives petunidin and malvidin. The same flavonols, quercetin and kaempferol, are also prosent in the two genera. These occur as glycosides before hydrolysis. 